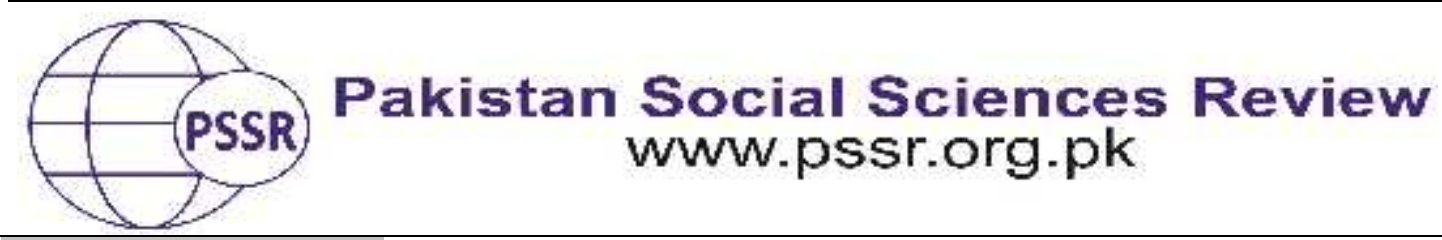

RESEARCH PAPER

Revisiting the Eighteenth Constitutional Amendment: Obscurities and Prospects

\author{
Jawwad Riaz ${ }^{1}$ Ali Nawaz Khan ${ }^{2}$ Zaheer Iqbal Cheema ${ }^{3}$
}

1. Assistant Professor, University Law College, University of the Punjab, Lahore, Punjab, Pakistan

2. Assistant Professor, University Law College, University of the Punjab, Lahore, Punjab, Pakistan

3. Assistant Professor, University Law College, University of the Punjab, Lahore, Punjab, Pakistan

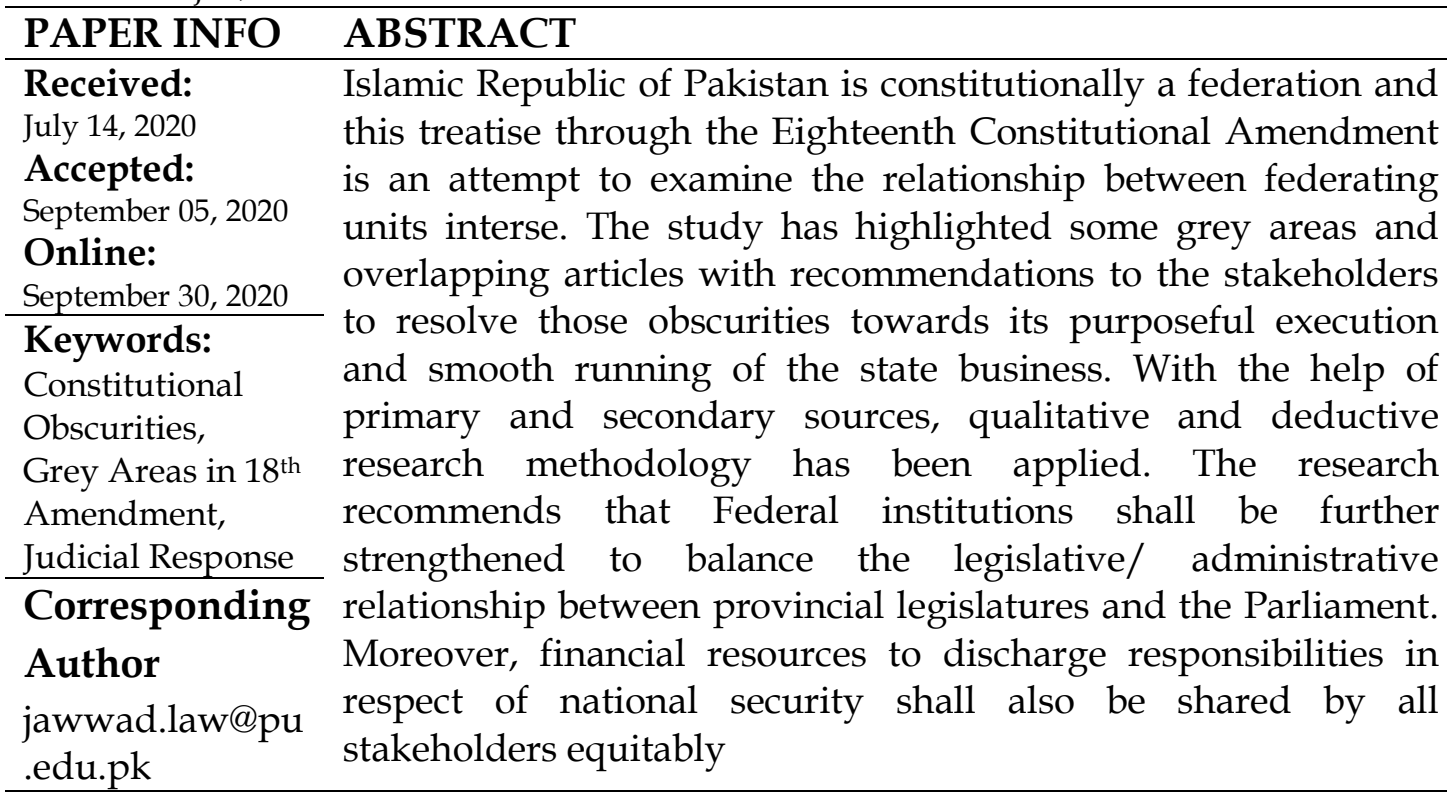

\title{
Introduction
}

Out of the thirty four amendments in the Constitution of Pakistan, 1973 (the Constitution) it is the $18^{\text {th }}$ Amendment (the Amendment) which has been irking the component political elements quite often. The amendment was brought through Majlis-e-Shoora (Parliament) Act No X of 2010. The aftermath calls for an objective examination to determine whether the reservations casually expressed by the critics have some grain of legitimacy or the same has been used only to gain some political mileage. The sincerity of purpose is a prerequisite for any critique. This paper is an attempt to objectively revisit the $18^{\text {th }}$ Constitutional Amendment, in order to have an in-depth examination that to what extent it has served the purpose of restoring the federal and parliamentary structure of the government, while ensuring maximum provincial autonomy and to highlight the bottlenecks towards its purposeful 
execution and smooth running of the state business. Furthermore, some grey areas and overlapping articles have been highlighted with recommendations to the stakeholders to resolve those obscurities.

\section{The Spirit of Constitution}

The Constitution of Pakistan is a blend of political systems, unlike United Stated of America which has Presidential form of Government with federating units or United Kingdom which has a unitary form of Government having no federating units and maintaining Parliamentary form of Government. Pakistan is a federation with Parliamentary form of Government at the federal and provincial levels. In addition, Pakistan is an ideological state based on Islam as immutable driving force (Pak. Const., Art. 2 \& 227). In a Federation, subject to the overall national interest, the interests of federating units are to be palatably harmonized. The constitution of a federation is normally rigid. For example, in over 200 years, the USA has made 27 amendments as compared to Pakistan wherein 25 constitutional amendments have brought forth in 73 years. In Pakistan, under Article 238 and 239 of the Constitution, an amendment can be brought by $2 / 3^{\text {rd }}$ majority in the National Assembly and Senate. Whereas, under Article V of the Constitution of the USA, the passage of an amendment bill by Congress requires $2 / 3^{\text {rd }}$ majority and ratification by $3 / 4^{\text {th }}$ of the total states is also required. In the given context, if a political party in Pakistan gets an overwhelming majority in Parliament the Constitution could become malleable for it.

The Constitution was made by consensus of all the political parties and provinces started with more than two pages of Preamble. All amendments excluding18 th had one line of Preamble (of expediency) whereas Act no X of 2010, the Preamble of $18^{\text {th }}$ Amendment in addition to expediency delineated four-lined objects which may be altruistic but smacks to be an attempt to rewrite the Constitution.

It is an admitted fact that in a federation there always remains a bickering for Provincial Autonomy, but that does not mean that the Constitution should readily be amended to douse the dissenting voices. Amendment in ordinary law and amendment in the Constitution are two poles apart. A very thorough homework at Provincial and Federal level is necessarily required to be made for a constitutional amendment. It cannot be denied that due to two intervening martial laws some provisions unbecoming of a Constitution had crept in the Constitution and there was no harm to restore the Constitution in its proper shape. After General Elections of 2008, both houses of Parliament passed two separate resolutions that a Committee should be constituted to revisit the Constitution. In light of those resolutions, a committee was constituted which had representation from all political parties. The Committee, after due diligence and brainstorming, submitted its recommendations. In light of those recommendations, $18^{\text {th }}$ Amendment to the Constitution was unanimously passed by the assembly. However, S M Zafar, a member of the Committee has said that sometimes you have to compromise to earn consensus. The $18^{\text {th }}$ Amendment retained basic features of the 1973 Constitution and country remained as the Islamic Republic has a federal structure with Parliamentary 
democracy. The independence of the judiciary was also ensured. Three important fundamental rights; namely, Right to Fair Trial (Art. 10A), Right to Information (Art. 19 A), and Right to Free Education (Art. 25 A) were granted to the people of Pakistan.

The Amendment also brought about changes to strengthen the countries primary institutions. The Election Commission of Pakistan has been strengthened through fixation of tenure of Chief Election Commissioner and its members. Their remuneration, mode of appointment and removal has been codified (Pak. Const. Part VIII). Furthermore, an attempt has been made to ensure the independence of the judiciary by the constitution of Judicial Commission of Pakistan and a Parliamentary Committee to finalize the names for appointment to the superior judiciary. The Council of Common Interest (CCI) has also been restructured by amending Article 153(2) of the Constitution. The Prime Minister being the Chairman, the Chief Ministers of the provinces and 3 nominees from the Federal Government would be members. The Council shall have its secretariat and must sit once in 90 days to deliberate and formulate policies in terms of entries combined in Part II of the Federal Legislative List (FLL) (Pak. Const. Art. 154). The Senate of Pakistan has also been strengthened through a number of changes: four additional seats were reserved for minorities and strength of upper house increased to 104 (Pak. Const. Art. 59). Earlier an Ordinance could successively be promulgated with cosmetic changes of course when the Parliament was not in session. Through the Amendment in Article 89, the Ordinance could not be extended after two terms of 120 days (Pak. Const. Art. 89). The Federal Cabinet was made responsible to the Senate as well as National Assembly (Pak. Const. Art. 91). The Senate of Pakistan was granted equal representation in Parliamentary Committee for the appointment of Judges (Pak. Cont. Art. 175-A) and $1 / 3^{\text {rd }}$ of the membership in Parliamentary Committee to appoint Chief Election Commissioner. The reports on Principles of Policy (Pak. Cont. Art. 29), Council of Common Interest, and (Pak. Cont. Art. 153), National Economic Council (Pak. Cont. Art. 156) in respect of Article 171 related to finances of the Federation by the Accountant General of Pakistan shall now be placed before Senate of Pakistan in the like manner as it was placed before the National Assembly. The Presidential power to dissolve the National Assembly under Article 58(2)(b) of the Constitution has been abolished. The Legal Frame Work Order (LFO) was undone en bloc. The other material changes were made in the Finances as contained in Article 160, 161 and 172 of the Constitution. The country moved from its traditional centric approach towards Provincial Autonomy.

\section{Constitutional Obscurities}

For the fear of longevity and propriety, it is not advisable to discuss the amendments threadbare. However, the surgical change was the abolition of the Concurrent Legislative List (CLL) containing almost 47 subjects. Before this Amendment, the Constitution had FLL (having Part I and Part II) and a CLL. By virtue of $18^{\text {th }}$ Constitutional Amendment, some items present in the erstwhile CLL 
were carried to the FLL in the Fourth Schedule and rest of it was abolished. Through the Amendment, Article 142 has been reworded to the effect that Parliament can make laws in respect of all the matters which the Constitution has assigned to the Federation in the light of Item No 58 of the FLL (Part I). Article 142 of the Constitution empowered both Parliament and Provincial Assemblies to make laws with respect to criminal law, criminal procedure and evidence. The Provinces could make legislation of all conceivable residuary subjects beyond the scope of FLL (schedule IV). Furthermore, some items present in Part I and Part II of the FLL have been reshuffled to bring under the domain of CCI to be dealt by the provinces and the federation commonly and are now carried in Part II of the FLL. In Continuation of this joint scope of legislative and executive powers, mineral oil and gas reserves are now shared by the Provinces and the Federation jointly and equally under newly added paragraph 3 to Article 172 of the Constitution. Furthermore, joint jurisdiction is provided to the Federation and the Provinces under Articles 157 and 161 in the matter of Production of Electricity, Natural Gas \& Hydro-Electric Power and Net Proceeds thereof (Engro v. FOP, 2012). In addition to that, Regulatory bodies (PEMRA, NEPRA, OGRA), which were created under the Item, all regulatory authorities established under a Federal Law are now present at Serial No 6 of Part II of FLL and falls within the domain of CCI.

Despite the fact $18^{\text {th }}$ Amendment aimed to ensure Provincial Autonomy, has given an edge to the Parliament over the provincial assemblies to exercise the executive authority to make laws provided under the Constitution. Article 97 determines the scope of executive authority of the Federation to all the matters concerning which Parliament has jurisdiction to make laws. FLL under Article 70(4) present at Fourth Schedule of the Constitution carries all those matters where Federation can make Laws. However, the Proviso to the aforementioned Article 97 provides that subject to any law made by the Parliament, the executive authority of the Federation may be exercised and extended to any matter which also comes within the scope of a Provincial Assembly. The Constitution has set the "extent of the executive authority of province" to all matters within the legislative scope of a provincial assembly under Article 137 of the Constitution. However, this executive authority of Province is limited by any law made by the parliament or its authorities under the Constitution. Through this rider given in the proviso to Article 137, the Federation has been given an edge to legislate in any matter where both Parliament and Provincial Assembly may legislate.

Another obscurity is present in the constitutional structure of the Federal and Provincial Governments provided by the Constitution under Article 90 wherein the Federation's executive authority shall be exercised on behalf of the President by the Federal Government consisting of the Prime Minister and the Federal Cabinet acting through the Prime Minister who shall be the Federation's Chief Executive. However, same structure has not been provided in the corresponding Article 129(1) for the Provincial Governments wherein the Chief Minister has not been declared Chief Executive of the province. 
The Constitution does not clearly lay down the responsibility of Law and Order in the country between the Federation and the Provinces. In the erstwhile CLL, Criminal Law and Criminal Procedure were at serial No 1 and 2 respectively. They are now moved to Article 142(b). However, preventive detention for reasons connected with the maintenance of public order, which was previously Item No 14 of the erstwhile CLL, after abolition, has now become subject of Provincial Assembly. It has become confusing to properly determine the responsibility and extent of authority in the light of Article 142 read with the Fourth Schedule to the Constitution on the wake of the socio-legal situation of law and order Pakistan has been facing. It is advisable to fix the constitutional responsibility to cure this obscurity.

Public debt, its supervision and maintenance is yet another confusing subject. The Constitution has overlapping provisions. Part I of the FLL at Serial no 10 carries Public Debt of the Federation but another similar item "Supervision and Management of Public Debt" is present at Serial No 8 of Part II of FLL. Allowing the Provinces to raise international loans through Article 167(4) appears to be unnecessary and conferring excessive autonomy creating hardships at the Federal level.

There is a question mark over the utility of FLL division into Part I and Part II. The CCI has powers under Article 154 of the Constitution to formulate policies concerning subjects carried in Part II of the FLL. However, the same Article authorizes Federal Government to issue directions to the CCI towards policymaking. The decision of Parliament would be final in case of dissatisfaction of any Government, Federal or Provincial (Pak. Cont. Art. 154(7)). Furthermore, FLL was divided into Part I and Part II in the light of Articles 70 and 71 before their amendment and abolition by Presidential Order 14 of 1985 and then in 2010 by Act No X of 2010. It was then provided that any Bill in respect of matters contained in Part I of FLL shall originate in the National Assembly under Article 70 and a Bill in respect to any matter in part II of the FLL or the CLL may originate in any House under erstwhile Article 71. Now, a Bill, except money Bill, may be introduced in any House so this bifurcation has as such a little meaning.

\section{Judicial Response}

The SC in the judgment ('Secretary Health v. Dr.Nadeem Rizvi', 2019) discussed the legality and vires of the action whereby certain federal institutions were transferred to the provinces from Federation in the light of Eighteenth Amendment to the Constitution. The Court ruled in favour of the Federation and held that any institution or entity that has been formed by the Federal Government through federal legislature and carries out functions that fall within the FLL are to be under the control and authority of the Federal government exclusively and such institutions cannot be devolved upon to the Provincial governments. It was held that the interpretation of the Legislative List must be liberally construed and widest possible meaning shall be given. The Court while admitting that the hospitals along 
with public health, under the Amendment is now a Provincial subject, however, $18^{\text {th }}$ Amendment could not prevent the Federal Government to provide healthcare facilities to the people in any of the Provinces. In the instant case, the honorable Court held that provision of a basic health facility is a Fundamental Right under Right to Life provided under Article 9 of the Constitution. It would be against the basic principle of Federalism if the Federal Government is deprived off exercising her authority to provide Fundamental Rights guaranteed by the Constitution. The judgment further provided that with respect to these institutions or other institutions established under the Federal legislation, if these institutions carry out functions which fall under the domain of the provinces, or the provinces have been delegated power through the FLL to exercise control over such functions, only then would the province have the authority to regulate the functions of these entities. This authority would be subject to the requirement that such institutions have lands / properties located within the territorial jurisdiction of that province.

The SC also discussed the subject matter of Education. Traditionally, the Subject of Education was in erstwhile CLL at Serial No 38 as "Curriculum, syllabus... standards of education" and at Serial No 39 as "Islamic Education". In addition to deleting CLL, the Amendment has also omitted Sixth and Seventh Schedule from the Constitution of Pakistan 1973. Resultantly, the constitutional protection against Amendment, Repeal or Alteration without the prior consent of the President to "The Privately Managed Schools or Colleges (Taking Over) Regulation 1972" presents as Entry No 16 had been revoked (Pak. Cont. Sch. VI Repealed). Likewise, the special protection against an amendment by following the ordinary procedure of law provided for an amendment to a statute, has also been revoked for some education sector statutes (Pak. Cont. Sch. VII Repealed). Before the amendment, Education was a common subject matter between the Provinces and the Federation. The Federation provided policy guideline, national curriculum (Federal Supervision of Curricula Act 1976, Sec 3(2)(a)) through the Ministry of Education at the Federal Level and Provinces had developed their own implementation schemes in the light of policy guideline provided by the Federation (I-SAPS 2014). The Federation had an upper hand in regulating higher education as well through Higher Education Commission (HEC) constituted under Higher Education Commission Ordinance 2002.

Post Eighteenth Amendment, some new entries in the Part II of the FLL have been inserted having a direct bearing on the Education sector vis-à-vis Regulatory Authorities established under the Federal Law (Entry No 6 FLL Part II), legal, medical and other professions (Entry No 11 FLL Part II) standard of higher education, research, scientific and technical educational institutes (Entry No 12 FLL part II) and interprovincial coordination and allied matters (Entry No 13 FLL Part II) were given under the mandate of CCI. After Eighteenth Amendment, Education has devolved as a Provincial subject to legislate upon. The role of Federation has been restricted to the extent of quality of Higher Education, research and management of legal, medical and other professions through the CCI. Provinces were given autonomy to legislate upon curriculum, infrastructure etc. The critics of the Eighteenth 
Amendment argue that devolution of Education to the Provinces has compromised the imparting of uniform quality education throughout Pakistan.

Supreme Court of Pakistan, in the matter of Petition regarding the miserable condition of the schools has observed that post-Eighteenth Amendment, the subject of education has devolved to the Provinces and it is their primary responsibility that children receive education as Fundamental Right. The Court not only made Right to Education (Pak. Cont. Sch. Art. 25 A), judiciable but also gave some legitimacy to the Federal Government to legislate upon Education to impart quality education to the children as a Fundamental Right. The apex court in the judgment reported as $P B C V S$ FOP held that State is responsible for ensuring fundamental rights and directed Secretary Law \& Justice Division to provide adequate funds to the Committee constituted by the SC to raise the standard of the legal education and to formulate policy to regulate affiliation/ recognition of law colleges across Pakistan.

The role of CCI interest was examined in PMDC Vs Fahad Malik In the light of post-eighteenth Amendment scenario whereby "legal, medical and other professions" were included in Part II of the FLL (Pak. Cont. Sch. IV, Entry No 11). The question examined was whether the prior approval of Council of Common Interest was necessary before promulgating the Medical and Dental Council (Amendment) Ordinance, 2013 and the Ordinance of 2014 and 2015, to amend the Ordinance of 1962. The court has held that the role of the CCI is limited to formulating policies for items/activities that fall under Part II of the FLL. However, the Federal government/legislature will have exclusive authority/ autonomy to regulate and enact laws with regards to items falling in the FLL and the CCI cannot interfere in this process. Additionally, the Parliament can on its own enact laws and does not require the prior approval of the CCI or any other body as it is the supreme lawmaking authority.

As evident from above case laws, it can be concluded that the SC has extended the responsibility of imparting quality education to different sections of the society while recognizing it as a Fundamental Right in the light of Article 9 of the Constitution on Federal Government as well. It is the responsibility of the state to promote the educational interest of backward classes and to provide primary and secondary education (Pak. Cont. Art 37).

In the matter of Sindh Revenue Board (2017) the question in hand was whether the Constitution under post-Eighteenth Amendment grants powers to the Sindh legislatures to impose sales tax on Civil Aviation Authority; and if it did, was Civil Aviation Authority providing services on which sales tax could be imposed? The court analyzed that any entity/corporation which has been enacted by the Federal Government or through Federal Legislation and carries out activities/functions that come under the FLL of the Constitution then the Federal Government would have exclusive authority to take any step including imposing sales tax on the said entity/corporation and the Provincial Government cannot take any action nor direct the entity/corporation to interfere with the activities of the Federal 
entity/corporation to comply with its laws including imposing any sales tax on it. Since the Civil Aviation Authority, being a Federal Regulatory Authority, performs functions carried in the FLL which falls within the exclusive scope of Federal Legislature, the Sindh Government cannot impose sales tax on the services provided by the Civil Aviation Authority.

The Supreme Court of Pakistan examined the scope of Federal and Provincial Legislature in the matter of Sui Southern Gas (2018) wherein the Industrial Relations Act, 2012 was examined to see whether it is ultra vires to the Constitution as it encroaches upon the legislative authority of the Provinces in the light Articles 141 to 144 of the Constitution, The Court also examined the scope of Federal and Provincial Legislature competence in matters having extraterritorial jurisdiction. Summarily, the case of the Appellants was that after the abolition of the CLL, subject matters which were previously covered under Entries no 26 (about Labor and its welfare) and 27 (Trade Unions and labour-related disputes) now falls within the domain of Provincial Legislature alone under Article 142(c) of the Constitution. It was also argued that the legislative scope of Parliament is limited only to matters which are listed in the FLL. Further, under Article 142(c), Parliament can legislate on any subject enumerated outside FLL only in eventuality if Provincial Assemblies have passed a resolution to that effect. Since there has been no resolution to that effect, the promulgation of the Industrial Relations Act 2012 is unconstitutional and void. Reliance was placed on Air League of PIAC wherein it was held that subject of labor welfare and trade unions have devolved to Provinces after the Eighteenth Amendment. Additionally, it was also argued that Industrial Relations Act 2012 cannot be covered under Entry No 2 of the FLL, which intends to discharge liabilities under International Treaties and Conventions, especially, when the Provinces have already made laws to that effect.

On the other hand, the respondents argued that the subject of Labor and trade union is covered under several entries of FLL (entries Nos 3, 8, 27, 31, 32, 58 and 59 of Part I and entries No 3, 13 \& 18 of Part II of FLL). Additionally, a provincial law is restricted to the territorial limits of the province and cannot operate at transprovincial level. The Court while dismissing the Appeal held that that the Federal Government will have exclusive authority to legislate/ regulate with regards to the matters falling within the FLL and since trans-provincial companies/ interprovincial matters fall under the FLL, only the Federal Government/Legislature shall have authority to regulate matters with regards to the same. Additionally, the Court has held that the Provincial Government only has authority with regards to matters that come within its Provincial Limits and any matter/entity that operates beyond the Provincial Limits, the Federal Government shall have exclusive authority and would override the powers of the Provincial Government. Thus, the Federal Government has exclusive competence to regulate trade unions working at the transprovincial level, but the Provincial Government does not. However, in the case of establishments conducting business in any of the provinces, it shall be subjected to the laws of that concerned province. 
Mr Justice Khosa, while writing for the Supreme Court of Pakistan examined the legislative scope of Parliament and the Provinces in respect of "Police" as a subject matter in AD Khawaja's Transfer Case (Unreported) and declared "Police is a Concurrent Subject". While declaring Police as a concurrent subject, the Court has extended the Federal Government competence to legislate upon the matter. In a nutshell, the SC has maintained that both the Federation and the Provincial Legislatures shall work independently while respecting the Legislative domains of each other. Whilst determining the legislative scope of each, the Court has liberally constructed the scope of FLL entries in favour of the Federation. The Court has admitted extraterritorial legislative/executive authority of the Federation but has declined the same to Provinces. Furthermore, the Federation alone has the authority to decide upon all matters concerning the mutual interest of federating units herself or through Authorities in the light of Article 97 and 98 of the Constitution. Moreover, the Court has also restricted the role of the CCI towards policy-making only. It has been held that since CCI is responsible to the Parliament, she cannot exercise a supervisory role over Parliament. Furthermore, it has been held that positive enforcement of fundamental rights throughout Pakistan is the responsibility of the Federal government primarily and her authority to execute the same shall not be circumscribed only by an absence of an entry in the FLL.

\section{Conclusion}

Pakistan is a federation, with its federating units and the Constitution acknowledges and establishes a balance between the Federation and provincial autonomy, which has further been ensured by the Eighteenth Amendment. The Amendment brought about a change in the Pakistan's institutional contours from a highly centralized federation to a largely decentralized one. It was apparently not passed hurriedly but it can safely be said that more deliberation at the cost of time should have been made. The Parliamentary Committee on Constitutional Reforms did due diligence and produced a unanimous report. The Objectives behind the Amendment, inter alia, were to strengthen the federal system, to grant provincial autonomy, and to strengthen the institutions of the state. Therefore, the Constitution shall not be interpreted in such a way that it weakens the Federation and her institutions. The Apex Court has interpreted the relevant Articles accordingly.

Arguably, the Amendment has been a milestone in the constitutional history of Pakistan. However, there have been talks about the usefulness of the Amendment. It is always experience which sh0ows where the shoe pinches. The multifaceted question is whether the Federation within the scope of abridged legislative lists was capable of generating funds to meet its enormous duties as correspondingly obliged in the FLL? It goes without saying that despite her peaceful nature, the security of Pakistan, from internal and external threats, has always been an overriding concern (Khan, 1998). Moreover, subjects like education and health also related to "national security" (Abbas, 2020). The National Exchequer is "under-resourced" to discharge these liabilities. The share of the Provinces in the divisible pool currently stands at 
$57.50 \%$ under the $7^{\text {th }}$ NFC Award (Rev. Dept. GKP). This has largely affected the ability of the Federal Government to positively discharge her responsibilities. It is proposed that a consensus among shareholders shall be developed to either amend Article 160(3A) to increase the share of Federation or the Provinces contribute towards "National Security" from their resources. The later has affectively been tested in fight against COVID 19, when Provinces under the leadership of the Federation vide National Disaster Management Authority has successfully dealt with the pandemic. Furthermore, the Federation shall also increase her revenues through better finance governance.

The Amendment cannot bear fruit unless it has been implemented to its full potential. The foremost feature of the Amendment was the decentralization of the Power. However, it remained in theory at both Federal as well as Provincial level. For example, In the matter of Regulatory Bodies, which were established to act independently under the policy guidelines issued by the Federal Government, it has been observed that the Federal Government has always been inclined to direct these bodies rather than advising them, which is undermining the basic purpose of these bodies. Like National Finance Commission Award, the Provincial Finance Commission Awards were also necessary to flow the funds to districts equitably. The funds at provincial level lie with respective Chief Ministers. For the purposed purpose, Political, administrative and financial responsibility should be devolved to the Local Governments as required by Articles 32 and 140 A of the Constitution. Moreover, the intra Party elections in the political parties are very important for the growth of democratic values. It kills the hereditary trend in the political parties. Through Legal Framework Order 2002, a sub Article 17(4) had been added that every Political Party shall, subject to Law, hold intra party elections to elect its office bearers and Party Leaders. After its abolition, Political Parties Order 2002 makes it mandatory upon registered political parties to conduct intra party's elections. The Election Commission of Pakistan shall enforce this responsibility. Furthermore, it is an irony that after the abolition of erstwhile CLL of the Fourth Schedule, the Divisions of the Federal Government provided under the Rules of Business 1973 should have reduced but Divisions rather became double. The Rules of Business 1973 had been framed under Article 90 and 99 of the Constitution. Some vested interests for fear of displacement went on enhancing the Divisions in the name of their jurisdiction to legislate up to Islamabad Capital Territory. The usefulness or otherwise remained opaque due to jaundiced implementation. It is suggested that Council of Common Interest, being heart of the Federation (Rabbani, 2016) shall be more proactively functional and the Provinces shall grasp its constitutional spirit and utilize the institution (Khan, 2017). The Senate of Pakistan shall also be given more powers to safeguard interest of the smaller provinces.

Constitution of a country is a dynamic organism and is testified by Part XI (Amendment) itself. In a democratic polity, the Constitution of a country embodies the set of formally decided rules and principles, which the people have decided to be governed with (Kazimi, 2009). The Constitution is not a rigid document and is open to amendments through a prescribed process to accommodate the will of the people. 
The SC of Pakistan is the Guardian of the Constitution and being the August Court is very much mindful and functional. In the next General Elections, the Political Parties must spell out clearly about their stances to bring about any amendment in the Constitution if so required for determination of will of the people. 


\section{References}

Abbas, M. (2020, May 10). Making of the Amendment, The News

Act No X of 2010, (2010). The Gazette of Pakistan

Air League of PIAC Employees through President Vs Federation of Pakistan \& others 2011 SCMR 1254

Bengali, Dr Kaiser. (2015). A Step towards Fiscal Autonomy, UNDP. Development Advocate Pakistan, Vol 2, Issue 1, 1-26

Constitution of Islamic Republic of Pakistan, (1973)

Engro Fertilizer Ltd Vs Federation of Pakistan 50 CLD (2012)

Federal Supervision of Curricula, Text Books and Standards Act, (1976)

Government of Sindh E others Vs. Dr Nadeem Rizvi \& Others 2019 SCMR 556

Implementation of the Eighteenth Constitutional Amendment: Briefing Paper on "Regulatory Bodies" Published by Fredrich -Ebert-Stiftung Pakistan and Pakistan Institute of Parliamentary Services 2017

Kazimi, M. R. (2009). A concise history of Pakistan. Oxford University Press

Khan, Zafarullah, (2017). The Council of Common Interests (CCI): Understanding and Strengthening the Institutional Aspects, Implementation of $18^{\text {th }}$ Constitutional Amendment, Friedrich-Ebert-Stiftung Pakistan

Khan, A.A., (1998). Security and Defence Problems of Pakistan, Defence Journal

Khan, M. Z., \& Education, C. Post 18th Constitutional Amendment: FederalProvincial Roles and Responsibilities.

Nuri, M H., (2011). Eighteenth Amendment Revisited, Islamabad Policy Research Instituted and Hanns Seidel Foundation (HSF), Germany

Pakistan Bar Council Vs Federal Government, 1651SCMR (2013)

Pakistan Medical and Dental Council \& Others Vs Muhammad Fahad Malik and others, 1956SCMR (2018)

Petition regarding the miserable condition of the schools 296 SCMR (2014)

Revenue Distribution under 7th NFC Award, Finance Department, Government of Khyber Pakhtunkhwa. 
Secretary Health Department \& Others Vs Dr. Nadeem Rizvi and others 556 SCMR (2019)

Sindh Revenue Board Vs the Civil Aviation Authority, 1344SCMR (2017)

Sui Southern Gas Company \& others Vs Federation of Pakistan, 802SCMR (2018) 